\title{
Towards Sustainable Middle Eastern Cities: A Local Sustainability Assessment Framework
}

\author{
Mustafa Al-Alwani \\ Faculty of Engineering, University of Babylon, Hilla, Babil, Iraq \\ E-mail: mustafalwani@yahoo.com \\ Steve Goodhew
}

School of Architecture, Design and Environment, Plymouth,Plymouth University, Uk

E-mail: $\underline{\text { S.Goodhew@plymouth.ac.uk }}$

Wei Pan

Department of Civil Engineering, Pokfulam, Hong Kong of University

E-mail: wpan@hku.hk

\begin{tabular}{|l|l|l|}
\hline Submission date:- 4/4/2019 & Acceptance date:- 16/4/2019 & Publication date:-6/5/2019 \\
\hline
\end{tabular}

\begin{abstract}
To assist in making Middle Eastern cities more sustainable a guiding methodological framework for local sustainability assessment is key to achieving a sustainable future. This paper investigates available frameworks and develops an approach to local sustainability assessment (LSA), by constructing a methodological framework utilising a combination of (bottom-up) and (top-down) approaches. This facilitates the formulation, selection and prioritisation of key indicators, which can then guide the assessment of a city's sustainability at a local level in the Middle East. The paper finally applies the LSA methodological framework to the Iraqi city of Hilla and succeeds in formulating and ranking 57 useful and valid sustainability indicators.
\end{abstract}

Key Words: Indicators, Local sustainability, Middle Eastern cities, Sustainability assessment framework.

\section{Introduction}

Since the Rio Summit in 1992 most local authorities and Local Agenda 21 groups have been developing Local Agenda 21 strategies. They have designed or developed indicators to increase their understanding and to observe and report on progress in delivering sustainable development locally. However, in addition to many problems such as rapid population and development growth, increasing emphasis on using cars, and poorly developed public transportation systems, many Middle Eastern cities have suffered from conflicts and instability. All these issues have led to sustainability challenges that influence the ability to attain social, environmental, economic and institutional goals in many Middle Eastern cities [1]. In these circumstances, a clear set of indicators can help local governments identify and attempt to correct social, economic and institutional problems, devising strategies for environmental improvement. Additionally, the development of sustainability indicators provides a way of engaging with the local community and offering an effective tool for decision making support [2]. This is particularly important in a post conflict situation where sustainability indicators at a local level can influence urban planning and management, focused on reconstruction and the monitoring and evaluation of policies and local decision-making [2]. Frameworks encourage interpretation and make the indicators more effective. They assist, explain and emphasise what to measure, what can be predicted from measurement and which indicators can be used [3]. If there is no framework, indicators will be unplanned, partial and will be aligned to particular knowledge; thus making interpretation more difficult, as research is excessively dense in some regions yet sparse in other significant regions [3]. 
There are no exact frameworks that allow one to facilitate or predict interactions that govern sustainability [4]; moreover, there are indicator frameworks which have been developed for use at the national, regional and local levels as well as for sectors, companies and even households. Thus, this article aims to contribute to the body of knowledge in this area by developing a practical approach to local sustainability assessment (LSA), a methodological framework, that combines Bottom-Up and Top-Down approaches. This provides a flexible, participatory and systematic approach that will facilitate the formulation, selection and priorities of key indicators which can then guide the assessment and action to improve sustainability at a local level in Middle Eastern cities.

\section{Review of Sustainability Indicator Frameworks}

A review of existing indicator frameworks provides a means of establishing the key dimensions for a strong framework for assessing sustainability.Studies have identified a variety of approaches to the creation of sustainability indicator frameworks, which can be used to restructure the selection and development of a conceptual framework for measures, such as [5].

There are no exact frameworks that allow one to facilitate or predict interactions that govern sustainability [4]; however, there are indicator frameworks, which have been developed for use at the national, regional and local levels as well as for sectors, companies and even households. Beyond the choice of framework, a further variable is the level of public participation involved in the production of framework indicators, which can range from high to non-existent [6].

Maclaren [7] summarizes this diversity by enumerating the main framework types, which could be used in order to develop sustainability indicators, including domain-based frameworks, goal-based frameworks, sectoral frameworks, issue frameworks, causal frameworks and combination frameworks. He characterises each one as shown in Table.1

Table 1 The main framework types used for developing sustainability indicators: [7]

\begin{tabular}{|c|c|c|}
\hline $\begin{array}{c}\text { Framework } \\
\text { types }\end{array}$ & Description & Advantage and disadvantage \\
\hline $\begin{array}{c}\text { Domain- } \\
\text { Based } \\
\text { Frameworks }\end{array}$ & $\begin{array}{l}\text { Uses the major dimensions of } \\
\text { sustainability (environment, } \\
\text { economy, and society) and then } \\
\text { recognises indicators for each. } \\
\text { Seattle's sustainability report is one of } \\
\text { the well-known examples of a } \\
\text { domain-based framework. }\end{array}$ & $\begin{array}{l}\text { The key strength of this framework type is that } \\
\text { it ensures coverage of the dimensions of } \\
\text { sustainability. However, its weakness is that it } \\
\text { does not appear to connect indicators with } \\
\text { sustainability goals. }\end{array}$ \\
\hline $\begin{array}{l}\text { Goal-Based } \\
\text { Frameworks }\end{array}$ & $\begin{array}{l}\text { Starts with the identification of } \\
\text { sustainability goals for a community } \\
\text { and then produces indicators for each } \\
\text { goal or combination of goals. The } \\
\text { United Kingdom's Local Government } \\
\text { Management Board (LGMB) is an } \\
\text { example of an agency that uses a } \\
\text { goal-based framework (LGMB, 1993) }\end{array}$ & $\begin{array}{l}\text { The advantage of this framework type is that it } \\
\text { decreases the number of indicators that have to } \\
\text { be considered to only those relating to } \\
\text { specified sustainability goals. This helps in } \\
\text { evaluating whether indicators are showing } \\
\text { movement towards or away from } \\
\text { sustainability. However, the disadvantage is } \\
\text { that it is quite simple and does not pick up } \\
\text { some of the complex interrelationships among } \\
\text { a variety of dimensions of sustainability. }\end{array}$ \\
\hline $\begin{array}{c}\text { Sectoral } \\
\text { Frameworks }\end{array}$ & $\begin{array}{l}\text { Develop indicators of sustainability } \\
\text { for each sector under the } \\
\text { responsibility of municipal } \\
\text { government, e.g. housing, } \\
\text { transportation, waste management, } \\
\text { land use, police services. These } \\
\text { sectors can be joined to individual } \\
\text { government departments, which helps } \\
\text { determine accountability for a }\end{array}$ & $\begin{array}{l}\text { A disadvantage of this framework is that the } \\
\text { division of indicators into specific areas of } \\
\text { government responsibility makes it difficult to } \\
\text { establish connections across dissimilar areas } \\
\text { of intervention. }\end{array}$ \\
\hline
\end{tabular}




\begin{tabular}{|c|c|c|}
\hline & $\begin{array}{l}\text { particular problem or credit for the } \\
\text { positive outcomes revealed by } \\
\text { indicators. }\end{array}$ & \\
\hline $\begin{array}{c}\text { Causal } \\
\text { Frameworks }\end{array}$ & $\begin{array}{l}\text { Seek to address the limitations of the } \\
\text { previous framework approaches by } \\
\text { introducing the concept of cause-and- } \\
\text { effect relationships. }\end{array}$ & $\begin{array}{l}\text { The advantage of this type of framework is } \\
\text { that it should be capable of explaining why } \\
\text { indicators are changing and whether policy } \\
\text { interventions are having an impact. }\end{array}$ \\
\hline $\begin{array}{l}\text { Issue-Based } \\
\text { Frameworks }\end{array}$ & $\begin{array}{l}\text { These frameworks list the } \\
\text { sustainability issues facing a } \\
\text { community, such as waste } \\
\text { management, air pollution, education, } \\
\text { and employment }\end{array}$ & $\begin{array}{l}\text { The key advantage of the issue-based } \\
\text { frameworks is that they are more } \\
\text { understandable and simple to construct, while } \\
\text { the disadvantage is that there is limited match } \\
\text { between indicators and sustainability goals, } \\
\text { and inadequate coverage of the main } \\
\text { dimensions of sustainability. }\end{array}$ \\
\hline $\begin{array}{l}\text { Combination } \\
\text { Frameworks }\end{array}$ & $\begin{array}{l}\text { This type of framework brings } \\
\text { together two or more of the individual } \\
\text { frameworks. By using a combination } \\
\text { framework, a lot of the disadvantages } \\
\text { of the individual frameworks } \\
\text { described above can be overcome. }\end{array}$ & $\begin{array}{l}\text { Since this framework approach brings together } \\
\text { two or more of the individual frameworks, it } \\
\text { may establish the advantages of some } \\
\text { individual frameworks while at the same time } \\
\text { overcoming some of their weaknesses. }\end{array}$ \\
\hline
\end{tabular}

Nathan and Reddy [8] examined commonly used sustainability frameworks for indicator development and identified the frameworks as shown in Table. 2.

Table 2 commonly used sustainability frameworks for indicator development, [8]

\begin{tabular}{|c|c|c|}
\hline Framework types & Description & Advantage and disadvantage \\
\hline $\begin{array}{l}\text { Capital Accounting } \\
\text { Framework }\end{array}$ & $\begin{array}{l}\text { This framework finds its origin in } \\
\text { economics and was developed } \\
\text { before the development of the } \\
\text { concept of sustainability. The } \\
\text { framework is used in } \\
\text { environmental accounting where } \\
\text { changes in natural resources are } \\
\text { calculated like financial resources. } \\
\text { In addition, social indicators are } \\
\text { yet to be included in this } \\
\text { environmental-economic } \\
\text { accounting framework (Lundin, } \\
\text { 2002). }\end{array}$ & $\begin{array}{l}\text { The advantage of this framework } \\
\text { lies in the fact that the connection } \\
\text { to mainstream accounting allows } \\
\text { comparability across } \\
\text { environmental qualities as well as } \\
\text { objectivity. On the other hand, } \\
\text { the disadvantage is that it is not } \\
\text { easy to quantify the qualitative } \\
\text { environmental resources. }\end{array}$ \\
\hline $\begin{array}{l}\text { Issue -based, goal-oriented } \\
\text { or thematic framework }\end{array}$ & $\begin{array}{l}\text { These frameworks are usually } \\
\text { created as a result of special } \\
\text { interests at local, national and } \\
\text { global levels (Newton et al., 1998) } \\
\text { and together with the pressure- } \\
\text { state-response (PSR) is found } \\
\text { widely in the indicator literature. } \\
\text { UNCSD has adopted a thematic } \\
\text { framework, as the programme was } \\
\text { created from Agenda } 21 \text { and } \\
\text { divided into themes and sub- } \\
\text { themes. Furthermore, they are } \\
\text { categorised into four dimensions } \\
\text { of sustainability: social, economic, } \\
\text { environmental and institutional } \\
\text { [9]. The indicators are goal-driven } \\
\text { and develop on the basis of various } \\
\text { themes and issues. }\end{array}$ & $\begin{array}{l}\text { The advantage of this framework } \\
\text { is that the thought of connecting } \\
\text { indicators to goals and targets } \\
\text { enables their use in measuring } \\
\text { performance and helps } \\
\text { connecting indicators to policy } \\
\text { priorities. However, the } \\
\text { disadvantage is that a number of } \\
\text { the goal-oriented frameworks are } \\
\text { excessively specific and do not } \\
\text { reflect the multidimensional } \\
\text { nature of sustainability, except as } \\
\text { already accepted within the } \\
\text { policy procedure. As a result, } \\
\text { they are neither comprehensive } \\
\text { nor constant (IISD, 1999). }\end{array}$ \\
\hline
\end{tabular}




\begin{tabular}{|c|c|c|}
\hline Systems Framework & $\begin{array}{l}\text { This framework has been derived } \\
\text { by Newman et al.(1996). It is } \\
\text { developed from an expanded urban } \\
\text { metabolism model (EUMM). } \\
\text { EUMM demonstrates cities as } \\
\text { systems where the desired } \\
\text { outcome is enhanced lifestyle and } \\
\text { decrease of waste. }\end{array}$ & $\begin{array}{l}\text { EUMM as a concept is closely } \\
\text { related to paradigm of sustainable } \\
\text { development, where } \\
\text { sustainability goals, future } \\
\text { orientation and connections } \\
\text { among various dimensions are } \\
\text { made explicit (Australia, 1998; } \\
\text { Newton, 2001). Regardless of } \\
\text { its advantages over other } \\
\text { frameworks, this system } \\
\text { framework is not as widely used } \\
\text { as causal and thematic } \\
\text { frameworks. }\end{array}$ \\
\hline $\begin{array}{l}\text { Sectoral or domain } \\
\text { framework }\end{array}$ & $\begin{array}{l}\text { It is not a framework in itself but it } \\
\text { is used frequently in combination } \\
\text { with other frameworks. Indicators } \\
\text { are structured under capital } \\
\text { accounting, or causal or thematic } \\
\text { or system frameworks can be } \\
\text { grouped into different domains or } \\
\text { sectors before being finally listed. } \\
\text { Transport, domestic, commercial } \\
\text { and industrial activities may be } \\
\text { considered as sectors, which } \\
\text { generally aligns with city } \\
\text { government departments; } \\
\text { moreover, land, water, energy etc., } \\
\text { which are specific areas of interest } \\
\text { or expertise, may considered as a } \\
\text { domain under this approach. }\end{array}$ & \\
\hline
\end{tabular}

\subsection{International Frameworks and Common Local Frameworks}

International frameworks have been mentioned by Farsari and Prastacos [10] are as follows:

1. World Bank: measuring the wealth of nations

2. United Nations -CSD Indicators

3. Barometer of Sustainability

4. Ecological Footprint

5. Organization of Economic Co-operation and Development's (OECD) Pressure-State-Response framework

Besleme and Megan [11] identify three basic conceptual frameworks adopted by community indicator projects taking place around the world. These are as follows:

1. A framework to measure local sustainability by focusing on a vision for the community's long-term future; and using additional sustainability indicators to deal with the connections among a variety of topics.

2. Quality-of-life indicators framework, which differs from sustainability indicators frameworks in dealing with short-term goals and does not seek to address the need to demonstrate connections between indicator areas.

3. A performance evaluation framework, which pays attention to performance evaluation; as well as seeking to determine efficiency in the delivery of a particular set of public services.

\subsection{Potential Approaches to the Organisation and Design of Indicators}

The literature reveals a wide range of approaches to the organization and design of indicators that are top-down (expert), bottom-up (community) or a mixture of the two, with each having its own advantages and disadvantages [12].[13] also focused on expert-driven and community-driven indicator processes by classifying frameworks according to the wide methodological paradigms which are expert-led and top-down as opposed to community-based and bottom-up. Their argument is that these 
two approaches require integrating for greater understanding of system interferences [14]. Government involvement can increase data credibility while the involvement of citizens in the process of choosing indicators ensures they are relevant to the community [10]. Reed et al. [15] examined different approaches to developing methodological frameworks and sustainability indicators and characterized these as bottom-up or top-down approaches as shown in Table.3.

Table 3 Methodological frameworks for developing sustainability indicators showing their approach:[15]

\begin{tabular}{|c|c|c|}
\hline Framework & Description & Reference \\
\hline \multicolumn{3}{|c|}{ BOTTOM-UP APPROACH } \\
\hline $\begin{array}{l}\text { Softsystems } \\
\text { analysis: }\end{array}$ & $\begin{array}{c}\text { Based on experiential learning (Kolb, 1984) and systems thinking } \\
\text { (Von Bertalanffy, 1968) to develop indicators as a dimension of a } \\
\text { participatory learning process to improve sustainability with } \\
\text { stakeholders }\end{array}$ & {$[16]$} \\
\hline $\begin{array}{l}\text { Sustainable } \\
\text { livelihoods } \\
\text { analysis }\end{array}$ & $\begin{array}{c}\text { Develops indicators of livelihood sustainability that can observe } \\
\text { variation in human, social, natural, physical and financial capitals } \\
\text { built on the entitlement theory which is a theory of distributive } \\
\text { justice and private property created by Robert Nozick (Nozick } \\
1974: 150)\end{array}$ & {$[17]$} \\
\hline $\begin{array}{l}\text { Classification } \\
\text { hierarchy } \\
\text { framework }\end{array}$ & $\begin{array}{c}\text { Recognises indicators by increasing the resolution of the system } \\
\text { element being evaluated, e.g., when the element is soil, property is } \\
\text { productivity, the descriptor is soil fertility so the indicator will be } \\
\% \text { organic matter }\end{array}$ & {$[18]$} \\
\hline $\begin{array}{l}\text { The Natural } \\
\text { Step }\end{array}$ & $\begin{array}{c}\text { Characterises four conditions for a sustainable society by } \\
\text { developing indicators to recognize sustainability problems, visions, } \\
\text { and strategies }\end{array}$ & [19] \\
\hline \multicolumn{3}{|c|}{ TOP-DOWN APPROACH } \\
\hline $\begin{array}{l}\text { Panarchy theory } \\
\text { and adaptive } \\
\text { management }\end{array}$ & $\begin{array}{l}\text { Recognise where complex systems present an adaptive cycle by } \\
\text { using three wide groups of indicators. Additionally, the panarchy } \\
\text { framework suggests that key indicators fall into one of three } \\
\text { categories: wealth, connectivity, diversity }\end{array}$ & [20] \\
\hline $\begin{array}{l}\text { Pressure-state - } \\
\text { response (PSR, } \\
\text { DSR, and } \\
\text { DPSIR): }\end{array}$ & $\begin{array}{l}\text { Determines environmental indicators dependent on human } \\
\text { pressures on the environment, environmental states, and } \\
\text { community responses leading to change for environmental topics. } \\
\text { Late formats changed pressure by using driving forces. Driving } \\
\text { forces may be positive or negative, but pressures are always } \\
\text { negative (DSR) and contain environmental impacts (DPSIR) }\end{array}$ & [21] \\
\hline $\begin{array}{l}\text { A framework } \\
\text { for evaluating } \\
\text { sustainable land } \\
\text { management }\end{array}$ & $\begin{array}{l}\text { A procedure for developing sustainability indicators to keep the } \\
\text { social, economic and environmental opportunities for generations } \\
\text { present and future while preserving the quality of the land }\end{array}$ & $\begin{array}{l}\text { Dumanski, } \\
\text { Eswaran, } \\
\text { and King } \\
\text { (unpublished } \\
\text { manuscript) }\end{array}$ \\
\hline $\begin{array}{l}\text { Well-being } \\
\text { assessment }\end{array}$ & $\begin{array}{l}\text { Employs four indices to assess human and ecosystem wellbeing: a } \\
\text { human well-being index, an ecosystem well-being index, a } \\
\text { combined ecosystem and human well-being index, and measures } \\
\text { the impact of progress in human well-being on ecosystem health as } \\
\text { fourth index }\end{array}$ & [22] \\
\hline $\begin{array}{l}\text { Thematic } \\
\text { indicator } \\
\text { development }\end{array}$ & $\begin{array}{l}\text { Recognizes indicators in each of environmental, economic, social, } \\
\text { and institutional themes }\end{array}$ & [23] \\
\hline
\end{tabular}




\subsection{Some Indicator Initiatives}

There are many organizations and governments that have developed national and local initiatives. Nathan and Reddy [8] studied sixteen indicator initiatives which are summarized in Table.4. As may be seen from this table, most of the national initiatives are top-down while local initiatives are bottom-up. A multi-stakeholder approach, where the top-down and bottom-up approaches are combined to ensure all stakeholders are involved, yields the best results and has been established by South Africa [24], [25, and [26].

Table 4 Summary of indicator initiative studied [8]

\begin{tabular}{|c|c|c|}
\hline Project & Framework & Scope \\
\hline \multicolumn{3}{|c|}{ Top-down Approach } \\
\hline [27] & $\begin{array}{l}\text { Causal framework (PSR) used in } \\
\text { conjunction with sectoral grouping }\end{array}$ & $\begin{array}{c}\text { (International) } \\
\text { Country }\end{array}$ \\
\hline$[28]$ & $\begin{array}{c}\text { Causal framework (PSR with } 2 \\
\text { additional components) }\end{array}$ & $\begin{array}{c}\text { (International) } \\
\text { Country }\end{array}$ \\
\hline [29] & $\begin{array}{c}\text { Causal framework (a modified version of } \\
\text { PSR) }\end{array}$ & City \\
\hline$[30][31]$ & $\begin{array}{c}\text { Objective or goal } \\
\text { oriented }\end{array}$ & Country \\
\hline UNCHS $(2002,2004)$ & Objective or goal oriented & $\begin{array}{l}\text { (International) } \\
\text { Country }\end{array}$ \\
\hline Argentina (UNDSD, 2005) & Systems & Country \\
\hline Australia(1998) & Systems (EUMM Model) & Country \\
\hline [9] & Thematic & $\begin{array}{c}\text { (International) } \\
\text { Country }\end{array}$ \\
\hline \multicolumn{3}{|c|}{ Bottom-up Approach } \\
\hline $\begin{array}{l}\text { EU Local Sustainability } \\
\text { Indicator [32] }\end{array}$ & Thematic & $\begin{array}{c}\text { (International) } \\
\text { City (Local authority) }\end{array}$ \\
\hline UEQES [33] & Target based & City (cities of PRC) \\
\hline London QoL [34] & Objective or goal oriented & City \\
\hline Sustainable Seattle (2004) & Issue based and sectoral classification & City \\
\hline$[35]$ & Issue based and thematic classification & City \\
\hline \multicolumn{3}{|c|}{ Multi Approach } \\
\hline Canada [25] & Capital based & Country \\
\hline South Africa [24] & Causal framework (DPSIR) & Country \\
\hline New Zealand[26] & $\begin{array}{l}\text { Combination of Theme based and capital } \\
\text { model }\end{array}$ & Country \\
\hline
\end{tabular}

\subsection{Summary framework literature and approaches}

Through a review of existing types of sustainability indicator frameworks, a good level of understanding of the construction of indicators has been provided. This will assist the construction of a methodological framework to develop indicators to evaluate sustainability at the local level. Additionally, the advantages and disadvantages of these frameworks have been diagnosed to aid the choice and combination of frameworks LSA which will be established and applied in this paper (a combination between using a goal-based framework and using a CSD Theme Indicator Framework 2001). The combination framework LSA brings together two or more of the individual frameworks; therefore, it may provide the advantages of individual frameworks at the same time as overcoming some of their weaknesses.

\section{The LSA Methodological Framework}

To develop a practical approach to local sustainability assessment LSA, a methodological framework, which could be used as a tool and mechanism to propose a set of local indicators of the different dimensions (social, environmental, economical and institutional), suitable steps should be applied as shown in Figure 1. 


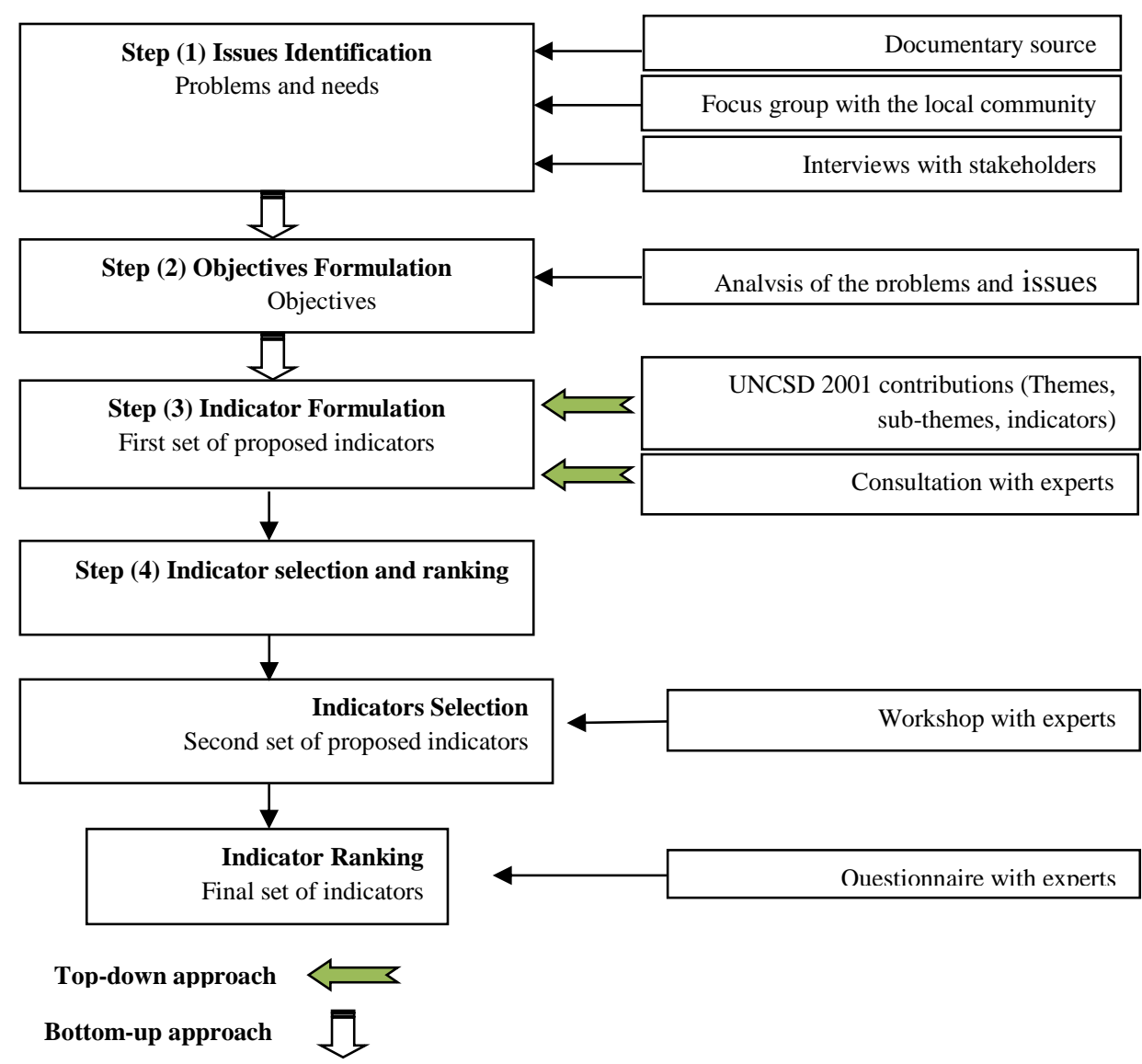

Figure 1 A detailed Scheme of the LSA methodological framework process

\subsection{Step One: Issues Identification (Bottom-up approach)}

This step defines the main sustainability problems and their root causes (social, economic, environmental and institutional). Documentary sources are used to assist the identification of the main problems. Moreover, strong community participation is essential from the start, through focus group meetings, in order to highlight local problems and wishes related to local sustainability. Furthermore, to collect further information, interviews with a range of stakeholders need to be performed. In this step (issues identification) the determining and setting/diagnosis of local sustainability aspects can be achieved, which is a critical step in the overall framework process.

\section{2 Step Two: Objective/Goal Formulation(Bottom-up approach)}

Step two formulates the scope of the framework to ensure that it addresses the key issues and problems emerging from Step one in relation to local sustainability. The framework should also provide a clear indication of what needs to occur in order to encourage local sustainability, as well as the programme for its achievement. Using the assessment of the problems and needs developed during the first step, the reformulation of those into solution statements or objectives is best prepared with the help of experts. The result of such reformulation must not lead to unmeaning solution statements (objectives).

\subsection{Step Three: Indicator Formulation ( Top down approach)}

Since each city is different, the suitable set of sustainability indicators will differ also, but as a starting point they may be chosen from any source and combined in the form that most suits the objectives included [36]. In this article the combination of the CSD Theme Indicators Framework (2001) contributions (themes, sub themes and indicators) with the Goal-Based Framework (indicators that most directly reflect the issues of a case study and its local communities and stakeholders) leads to the adoption of a top-down / bottom-up approach. It has 
been argued that such an approach is a superior way to develop indicators which are top-down/bottomup [37].

\subsection{Step Four: Indicator Selecting and Ranking}

There is a need for a systematic, auditable and transparent approach to the selection and identification of priorities of local sustainability indicators. Thus, this step contains two processes, indicator selection and indicator ranking.

\section{4.1 Indicator Selection}

The first set of potential indicators will be revised and analysed through a workshop with a panel of experts from various fields. This revision stage will be used to reformulate and select valid and useful indicators. This will decrease the number of indicators and make them methodologically strong, readying them for use in the final participative assessment process: a questionnaire.

\section{4.2 Indicator Ranking}

In this step the expert participants will be asked to choose the level of importance of each indicator listed in a questionnaire survey.

\section{The Case of Hilla}

Hilla city, Iraq is one of the Middle East cities with a total population of 484,007 people. It is located on both sides of the Hilla river which is a branch of the Euphrates river in the position of the intersection of longitude (44.26) east and with latitude (32.29) north [38].

The city of Hilla, Iraq has been selected as the single case study, because Iraq has characteristics typical of many other countries in the Middle Eastern area, especially as an oil rich country which has suffered from several conflicts, in addition to having similar cultural backgrounds and sustainability problems. Therefore, the city of Hilla relates to different Middle Eastern cities. There is unique opportunity for the city of Hilla because of its location close to the site of ancient city of Babylon, which have given the city a significant importance in terms of development opportunities Show Figure2.

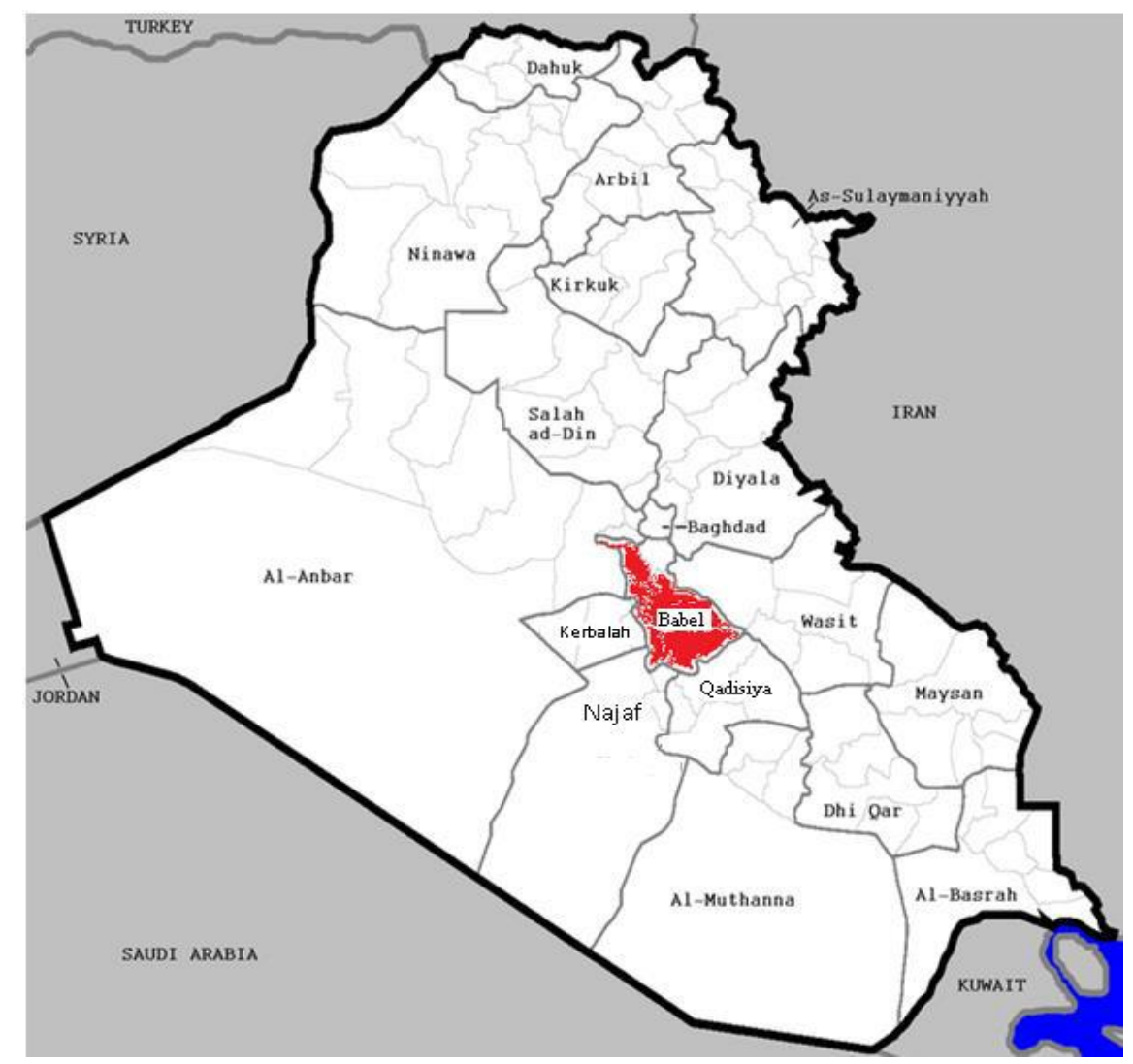

Figure 2 Hilla city location (Dar al Handasa, 2006) 
For applying the LSA framework there are four steps as flow:

The first step consists of issue identification and aims to explore the major issues, needs and problems within the city of Hilla, Iraq. Documentary sources used to collect the issues of the city of Hilla are: books, newspapers, journal articles, government records, unpublished reports, non-government reports, academic reports, local historical records, maps, socioeconomic studies and other sources relevant to the case study. Since, the city of Hilla is divided into four parts (heritage district, older suburbs, modern suburbs and recent slum), , in order to achieve a geographic representation of the population, the researcher sought to achieve meetings with residents from each of the four parts of the city.

A systematic process of sifting and sorting of material was applied to the document sources, focus groups and interview results. Moreover, each set of results were regrouped and classified according to the four dimensions (social, economic, environmental and institutional) and key themes as suggested by the CSD Theme Indicator Framework (2001) which adopted for the LSA methodological framework.

After that, the findings from the three data sources have been triangulated into a comprehensive whole to verify and validate the findings within this study. This led to creating a unified set which includes the triangulating valid results. This set of findings was used in the following step to formulate the objectives.

The second step reformulation of the unified set of problems and needs into solution statements or objectives were prepared with the help of an expert consultation from various fields. Generally, there was one objective formulated for each problem, but at most there was one objective for each two or more problems.

Through step 3 each indicator was being developed in consultation with experts from various fields and thorough a careful review of the literature in the environmental, social, economic and institutional fields. This step produced the first set of proposed indicators which contained 98 indicators. In general, the proposed indicators set has (48) social sustainability indicators, (14) environmental sustainability indicators, (21) economic sustainability indicators and (15) institutional sustainability indicators.

In the fourth step the first set of potential indicators was then analysed, revised and selected through a workshop with a panel of experts from various fields. This revision stage was used to reformulate and select useful indicators. This resulted in the production of a refined list of 57 useful and valid sustainability indicators. A group of forty experts (academics and practitioners) from the city of Hilla, Iraq, then contributed to the process by a questionnaire which uses an applied itemized rating scale for ranking indicators on the basis of priority (final set of indicators).

This application illustrates the capabilities, applicability and practicality of the LSA methodological framework (Table.5 shows top ten set of local sustainability indicators for the city of Hilla). 
Table 5 Top ten set of indicators suggested for measuring the sustainability of the city of Hilla

\begin{tabular}{|c|c|c|}
\hline Problems & Objectives & Indicators \\
\hline $\begin{array}{l}\text { - High unemployment } \\
\text { Lack of interest in graduates and } \\
\text { provides suitable job opportunities }\end{array}$ & $\begin{array}{c}\text { To reduce } \\
\text { unemployment }\end{array}$ & 1-Unemployment Rate \\
\hline - $\quad$ Poor enforcement of laws & To enforcement of laws & $\begin{array}{l}\text { 2-Number of crimes and terrorist } \\
\text { incident reported/ detected and } \\
\text { convictions per month }\end{array}$ \\
\hline - $\quad$ High rate of poverty & To reduce poverty & $\begin{array}{l}\text { 3-Proportion of population below } \\
1 \$ \text { a day }\end{array}$ \\
\hline $\begin{array}{l}\text { Inadequate supply of energy to meet } \\
\text { demand } \\
\text { Poor quality and unreliability of } \\
\text { electricity generation and supply } \\
\text { networks }\end{array}$ & $\begin{array}{l}\text { To deliver adequate and } \\
\text { reliable electricity } \\
\text { supplies to meet } \\
\text { demand }\end{array}$ & $\begin{array}{c}\text { 4-Number of hours of processing } \\
\text { power daily electricity }\end{array}$ \\
\hline $\begin{array}{c}\text { Lack of adequate housing for poorer } \\
\text { families } \\
\text { The presence of a large housing } \\
\text { deficit } \\
\text { The increasing phenomenon of } \\
\text { random housing } \\
\text { Expansion of slum housing units } \\
\text { Lack of housing for the families of } \\
\text { the martyrs, widows and poor } \\
\text { families } \\
\text { Increasing the number of displaced } \\
\text { families }\end{array}$ & $\begin{array}{l}\text { To eliminate of the } \\
\text { housing crisis }\end{array}$ & $\begin{array}{l}\text { 5-Number of people who do not } \\
\text { have suitable housing }\end{array}$ \\
\hline - $\quad$ Shortage of Doctors & $\begin{array}{l}\text { To increase the number } \\
\text { of doctors }\end{array}$ & $\begin{array}{l}\text { 6-The number of Doctors per } \\
1000 \text { people }\end{array}$ \\
\hline $\begin{array}{l}\text { Remoteness of schools for students } \\
\text { in some areas } \\
\text { Insufficiency of school buildings } \\
\text { Decrease in the number of primary } \\
\text { and secondary schools of the } \\
\text { population } \\
\text { Inadequacy of some schools for } \\
\text { students }\end{array}$ & $\begin{array}{l}\text { To provide a sufficient } \\
\text { number primary and } \\
\text { secondary school }\end{array}$ & $\begin{array}{l}\text { 7-Number of modern school } \\
\text { places per } 1000 \text { children of school } \\
\text { age by neighbourhood }\end{array}$ \\
\hline $\begin{array}{c}\text { - } \begin{array}{c}\text { Weakness of administrative } \\
\text { monitoring }\end{array} \\
\text { - } \quad \text { Increase of financial and } \\
\text { administrative corruption }\end{array}$ & $\begin{array}{c}\text { To eradicate } \\
\text { administrative and } \\
\text { financial corruption }\end{array}$ & $\begin{array}{l}\text { 8-Number of cases prosecuted of } \\
\text { financial and administrative } \\
\text { corruption in the institutions and } \\
\text { government departments }\end{array}$ \\
\hline $\begin{array}{c}\text { Inefficient or non-existent sewerage } \\
\text { network }\end{array}$ & $\begin{array}{l}\text { To improve sewerage } \\
\text { network }\end{array}$ & $\begin{array}{l}\text { 9- Percentage of population with } \\
\text { adequate sewage disposal }\end{array}$ \\
\hline - $\quad$ Shortage of nursing staff & $\begin{array}{l}\text { To increase the number } \\
\text { of nurses }\end{array}$ & $\begin{array}{l}\text { 10- Number of nurses per } 1000 \\
\text { people }\end{array}$ \\
\hline
\end{tabular}




\section{Discussion}

This paper has developed an approach to local sustainability assessment LSA, a methodological framework, that combines Bottom-Up and Top-Down approaches and provides a flexible, participatory and systematic approach that will facilitate the formulation, selection and priorities of key indicators of the different dimensions (social, environmental, economical and institutional). The developed approach should guide the assessment and appropriate actions to improve sustainability at the local level in Middle Eastern cities. The LSA methodological framework succeeded in formulating and ranking 57 useful and valid sustainability indicators related to the city of Hilla. Although the LSA methodological framework is strong enough, there are some of basic opportunities of the research and recommendations for further work such as identifying the indicators potential targets in order to demonstrate the goal accomplishment, enforcing a balance between the four pillars of sustainability to overcome the ignorance of some important sustainability issues and using a larger group of stakeholder in the application of the LSA methodological framework.

As a result, this paper has made a major contribution to the knowledge by developing an LSA methodological framework which can guide the assessment and action to improve sustainability at the local level in Middle Eastern cities.

\section{CONFLICT OF INTERESTS.}

- There are no conflicts of interest.

\section{References}

[1] Menichetti, D. and Vuren, T., Modelling a low-carbon city. Institution of Civil Engineers, 164, $141-151,2011$.

[2] Lombardi, P.L., Understanding sustainability in the built environment. A framework for evaluation in urban planning and design. Thesis (PhD). University of Salford, 1999.

[3] Bossel, H., Indicators for Sustainable Development: Theory, Method, Applications. Canada: International Institute for Sustainable Development, 1999.

[4] Abolina, K. and Zilans, A., Evaluation of urban sustainability in specific sector in Latvia. Environment, Development and Sustainability, 4 (3), 299-314, 2002.

[5] Walton, J. S., El-Haram, M., Castillo, N. H., Horner, R.M.W., Price, A. D. F. and Hardcastle, C., Integrated assessment of urban sustainability. Engineering Sustainability, 158, 57-66, 2005.

[6] Bell, S. and Morse, S., Measuring sustainability: learning by doing. London: Earthscan, 2003.

[7] Maclaren, V. W., Urban sustainability reporting. J Am Plann Assoc, 62 (2), 184-202, 1996.

[8] Nathan, H. S. K. \& Reddy, B. S., A conceptual framework for development of sustainable development indicators. Mumbai: Indira Gandhi Institute of Development Research, 2008.

[9] United Nations Commission on Sustainable Development (UNCSD), Indicators of sustainable development: framework and methodologies. New York: Division for Sustainable Development, United Nations, 1996.

[10] Farsari, Y., and Prastacos, P., Sustainable Development Indicators: An overview. Hellas: Institute of Applied and Computational Mathematics, 2002.

[11] Besleme, K. and Megan, M., Community Indicators and Healthy Communities. National Civic Review, 86, 43-53, 1997.

[12] Hart, M., Sustainable community indicator: trainers' workshop. West Hartford, US: HART Environmental, 1998.

[13] Reed, M. S., Fraser, E.D.G., Morse, S. and Dougill, A., Integrating Methods for Developing Sustainability Indicators to Facilitate Learning and Action. Ecology and Society, 10 (1), 2005.

[14] Sonntag V., Designing Sustainability Indicator Frameworks for Information Flow: A Case Study of B-Sustainable. Applied Research Quality Life, 5:325-339, 2010. 
[15] Reed, M, Fraser, E and Dougill, A., An adaptive learning process for developing and applying sustainability indicators with local communities. Ecological Economics, 59,406-418, 2006.

[16] Checkland, P., Systems thinking, systems practice. Chichester, UK: John Wiley, 1981.

[17] Carney, D., Sustainable rural livelihoods: what contribution can we make?. London: Department for International Development, 1998.

[18] Bellows, B. C., Principles and practices for implementing participatory and intersectoral assessments of indicators of sustainability: Outputs from the Workshop Sessions SANREM CRSP Conference on Indicators of Sustainability. SANREM CRSP Research Report, 1/95 243-268, 1995.

[19] TNS (Natural Step), The Natural Step. Available from: http://www .naturalstep. org/. [Access 5 April 2013], 2004.

[20] Gunderson, L., and Holling C. S., Panarchy: understanding transformations in human and natural systems. Washington:Island Press, 2002.

[21] EEA., Europe's environment: The second assessment. Copenhagen: European Environment Agency, 1998.

[22] Prescott-Allen, R., The well being of nations: a country-by country index of quality of life and the environment. Washington: Island Press, 2001.

[23] United Nations Commission on Sustainable Development, Indicators of sustainable development: framework and methodologies. New York (NY): United Nations Commission on Sustainable Development, 2001.

[24] DEAT, National Core Set of Environmental Indicators. For State of Environment Reporting in South Africa, Phase I, Scoping Report. Pretoria: National Department of Environmental Affairs and Tourism, 2001.

[25] NRTEE, Environment and Sustainable Development Indicators of Canada, State of the Debate. Canada: National Round Table on the Environment and Economy (NRTEE).Objectives in international agricultural research. Agricultural Economics, 3, 381-398, 2003.

[26] New Zealand, Monitoring Progress Towards a Sustainable New Zealand,An experimental report and analysis. Wellington: Statistics New Zealand, 2002.

[27] OECD, OECD Environmental Indicators: Development, Measurement and Use. Refereed paper, Environmental Performance and Information Division, Paris: Organization of Economic Cooperation and Development, 2003.

[28] WEF, Environmental Sustainability Index report -Benchmarking National Environmental Stewardship, World Economic Forum. Available from: www.yale.edu/esi [Accessed 10 June 2013], 2005.

[29] Dhakal S., Report on Indicator related research for Kitakyushu Initiative. Japan: Ministry of Environment, 2002.

[30] UK Government, Quality of Life Counts, Indicators for Strategy for Sustainable Development for the United Kingdom. London: Department for Environment, Food, and Rural Affairs (DEFRA), 1999.

[31] UK Government, Securing the Future, Delivering UK Sustainable Development Strategy. London: Department for Environment, Food, and Rural Affairs (DEFRA), 2005.

[32] Ambiente, I., European Common Indicators - Towards a Local Sustainability Profile. Final Project Report, Milano: Ambiente Italia Research Institute, 2003.

[33] Angel, D. P., Rock, M. T., and Frederick, M. D, Policy integration: Environment and Development in ASIA. Asian Environmental Outlook Series, Manila: Asian Development Bank, 2001.

[34] LSDC, A sustainable development framework for London. London Sustainable Development Commission, London, 2002. 
Journal of University of Babylon for Engineering Sciences, Vol. (27), No. (2): 2019.

[35] Winnipeg, City of Winnipeg Quality of Life Indicator. Winnipeg: International Institute of Sustainable Development (IISD), 1997.

[36] Valentin A. and Spangenberg JH., A guide to community sustainability indicators. Environmental Impact Assessment Review, 20, 381-92, 2000.

[37] O`Connor, M. and Spangenberg, J., A Methodology for CSR Reporting: Assuring a Representative Diversity of Indicators across Stakeholders, Scales, Sites and Performance Issues. Forthcoming in the Journal of Cleaner Production, 16 (13), 1399-1415, 2007.

[38] Al Khatib, S., M., City of Hilla, the major function and regional relations. Thesis (Msc.) Baghdad University, 1972. 


\section{نحو مدن شرق اوسطية مستدامة: أطلار لتقيم الاستدامة المحلية \\ وي بان \\ ستيف كوديو \\ مصطفى خضير العلواني}

الخلاصة

للمساعدة في جعل مدن الثنرق الأوسط أكثر استدامة، يعتبر إطار عمل منهجي توجيهي لتقييم الاستدامة المحلية هو الدفتاح

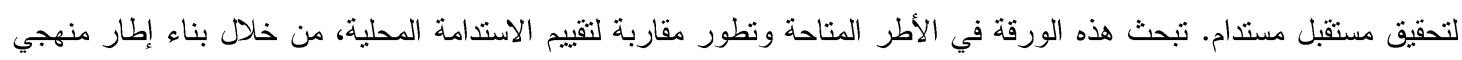

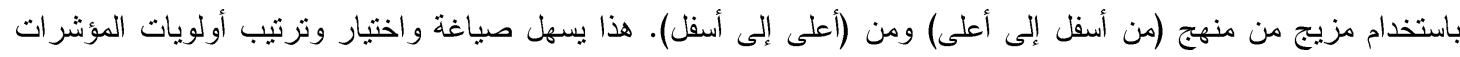

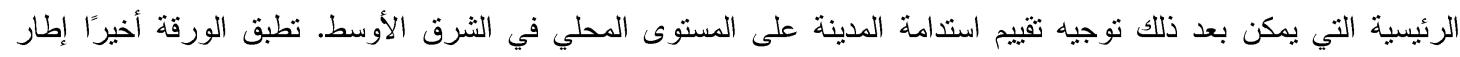
المنهجية على مدينة الحلة العر اقية وتتجح في صياغة وتصنيف 57 مؤشر أ صالحاً للاستدامة.

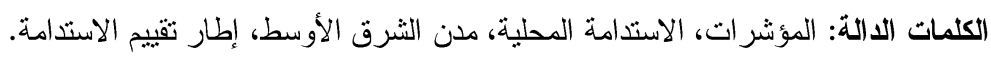

